\title{
Optimization of techniques and procedures for the production and management of live feed used in the larval culture of the freshwater shrimp Cryphiops caementarius (Decapoda: Palaemonidae)
}

\author{
Jorge E. Moreno-Reyes, María C. Morales, Carlos A. Méndez \\ Cármen A. Álvarez \& Jaime A. Meruane \\ Departamento de Acuicultura, Facultad de Ciencias del Mar \\ Universidad Católica del Norte, Coquimbo, Chile \\ Corresponding author: María C. Morales (mcmorale@ucn.cl)
}

\begin{abstract}
The variation in saline requirements during larval development of Cryphiops caementarius establishes a particular coexistence in the culture systems between the shrimp larvae, the microalgae and Artemia nauplii. Although the technology for the mass production of freshwater prawn juveniles has advanced positively, the non-commercial availability of an exclusive live feed for amphidromous crustaceans, such as $C$. caementarius, has created the need to optimize the management of organisms commonly used as feed in the larval culture of marine crustaceans. We investigated the effect of salinity on embryonic development dynamics and the hatching rate of commercial Artemia sp. cysts, including the effect of cooling decapsulated cysts on the hatching rate, and the effect of salinity on the behavior of marine microalgae used as live feed in the larviculture of $C$. caementarius. The results encourage a sustained and stable production of Artemia nauplii at different salinities, and at the same time, reduce by $80 \%$ the daily time used in feeding activities. Also, the information generated in this study adds critical information about activities and procedures for the larviculture of the northern river shrimp, which could be used to improve larval feeding strategies either in C. caementarius or in other amphidromous crustacean species.
\end{abstract}

Keywords: Cryphiops caementarius; Artemia; amphidromous; live feed; microalgae; aquaculture

\section{INTRODUCTION}

The global shrimp industry has seen widely recognized scientific and technological advances. However, existing information regarding technology for larval culture and production of juveniles of species of a commercial interest with amphidromic characteristics is still scarce in comparison with information available for marine species of the genus Penaeus (Lavens \& Sorgeloos, 1996; Bauer \& Delahoussaye, 2008). Cryphiops caementarius (Molina, 1782) (Decapoda: Palaemonidae), known locally in Chile as the northern river shrimp, is the most commercially important freshwater crustacean of northern Chile and southern Peru, with a restricted geographical distribution between $10^{\circ} \mathrm{S}$ (Hartmann, 1958; Bahamonde \& Vila, 1971) and 32 $55^{\prime}$ 'S (Meruane et al., 2006a). Due to its high commercial value as well as its high social and economic importance in Chile and Peru, this palaemonid has been subjected to excessive exploitation for years, impacting its natural populations throughout the Chilean territory. It is reported as a species in danger of extinction in Chile's Valparaíso and Metropolitan regions (from $32^{\circ} 03^{\prime} \mathrm{S}$ to $32^{\circ} 55^{\prime} \mathrm{S}$ ), and vulnerable for the rest of its distribution (Jara et al., 2006).

The vulnerable condition of $C$. caementarius as a native species and its attractive value in the local market has aroused a keen interest in technologies that produce juveniles in controlled cultivation conditions, both for restocking purposes and for commercial purposes. However, although the artificial production of $C$. caementarius juveniles has been investigated for several years by different authors (Sanzana, 1976; Norambuena, 1977; Viacava et al., 1978; Hernández, 1981; Sanzana \& Báez, 1983; Baéz et al., 1983-84; Rivera et al., 1987; Morales, 1997; Meruane et al.,

Corresponding editor: Patricio Dantagnan 
2006b; Morales et al., 2006), its commercial escalation has only been achieved in the last 12 years (Meruane et al., 2006a; Morales et al., 2006; Morales \& Meruane, 2012). The definition of biological factors, such as the duration of its larval development cycle, including 18 stages of zoea (Morales et al., 2006), the standardization of feeding protocols and the use of larval condition indicators, has been key to finalize the validation of results and the consolidation of crop technology (Meruane et al., 2006b; Morales et al., 2006; Morales \& Meruane, 2012).

The demand for procedures for producing live feeds with different saline requirements and the feed's adaptation to environmental conditions present in the C. caementarius larval culture is one of the main factors to be considered in feeding protocols, mainly regarding the saline changes necessary for the success of metamorphosis. Thus, the response of the live feed used (microalgae, brine shrimp, rotifers) must be in agreement with the salt concentrations used in the larviculture of $C$. caementarius, allowing it to remain available as prey within environmentally variable farming systems. To generate information that reduces production costs and optimizes operational processes associated with the culture technology of $C$. caementarius, the effect of salinity and the use of low temperatures in the production and conservation of commonly used live feed was investigated during the larval culture of the species.

\section{MATERIALS AND METHODS}

Three experiments were carried out, each focused on the improvement of processes and protocols for producing live feed as well as delivering the feed during the larval culture of $C$. caementarius. They were carried out in the crustacean culture laboratory, located in the facilities of the Universidad Católica del Norte, Coquimbo (2958'S; 71²1’ W), Chile.

\section{Effect of salinity on the production of Artemia sp. nauplii}

Commercial Artemia sp. cysts, that were previously hydrated and decapsulated according to the protocols of the crustacean culture laboratory of the University, were incubated at three different salinities $(13,15$ and 20 ) for $24 \mathrm{~h}$. The incubation density for this test was two grams of decapsulated cysts per liter of water. The effect of salinity on the dynamics of embryonic development and the percentage of cysts hatched was evaluated at 12, 16, 20 and $24 \mathrm{~h}$ of incubation, in $1 \mathrm{~mL}$ samples. The proportions of cysts, umbellar stages and nauplii were compared between salinities and between times using contingency tables. The hatching percen- tages (proportion of nauplii produced divided by the total number of cysts incubated) were compared using the analysis of variance test (one-way ANOVA), followed by the Holm-Sidak multiple comparisons test, when relevant.

\section{Effect of refrigeration of decapsulated cysts on the production of Artemia sp. nauplii}

Pre-hydrated and decapsulated commercial cysts were placed in glass containers with fresh drinking water and refrigerated at a temperature of $0.5 \pm 0.2^{\circ} \mathrm{C}$. The effect of storage at low temperatures on cyst viability was evaluated daily for 15 days based on the percentage of cysts hatched at $24 \mathrm{~h}$ of incubation. For this test, the cysts were incubated in brackish water at 20 of salinity and a density of $1 \mathrm{~g}$ of dehydrated cyst per liter of water. The number of nauplii was counted in $1 \mathrm{~mL}$ samples and compared with the 15 days of experimentation through the analysis of variance test (one-way ANOVA), followed by the Holm-Sidak multiple comparisons test, when relevant.

For the tests of Artemia sp., dehydrated commercial cysts (Bio-Marine brand) were used, and incubated at $28^{\circ} \mathrm{C}$ (laboratory protocol of crustaceans at the university), in plastic $1.5 \mathrm{~L}$ bottles with strong aeration. The number of replicates used for each experiment was $\mathrm{n}=3$. The quantification and sampling were performed in triplicate. Differences were considered statistically significant at $P<0.05$. The statistical evaluations of the data were carried out with the software Sigma Stat v.3.1. For calculations, the number of dehydrated Artemia sp. cysts contained in one gram by visual counting under a conventional magnifying glass was quantified, obtaining an average value of $306,000 \pm$ 25,100 . The cyst hydration and decapsulation processes were carried out according to the university working protocol of the crustacean laboratory. This protocol consists of 1) hydrating the Artemia sp. cysts in drinking water with strong aeration for one hour, to a density of two grams per liter, 2) decapsulate the previously hydrated cysts with $200 \mathrm{~mL}$ of decapsulating solution per gram of dehydrated cyst (50\% water and 50\% commercial sodium hypochlorite), for $6.5 \mathrm{~min}, 3$ ) wash the decapsulated cysts for $10 \mathrm{~min}$ with plenty of drinking water, 4) separate the decapsulated cysts from the non-decapsulated cysts by immersion in drinking water for $15 \mathrm{~min}$, subsequently removing the cysts, which remain floating.

\section{Effect of salinity on the behavior of microalgae used as live feed}

Cells of Nanochloropsis sp. and Isochrysis galbana of the Tahitian variety (T-Iso) were exposed individually 
and mixed in equal parts, at conditions of $20^{\circ} \mathrm{C}$ and saline concentrations of 20 and 15 , for $48 \mathrm{~h}$. All the tests were carried out without aeration in triplicate and under natural light conditions, using $10 \mathrm{~mL}$ cylindrical glass vial bottles with an area at the base of $1.5 \mathrm{~cm}^{2}$. The effect of salinity on microalgae was evaluated qualitatively by observing sediment formation inside the flasks (sedimented cells) and depending on changes in swimming and shape of the cells at 5, 10, 15, 20, 25 and $30 \mathrm{~min}$, and later at 2, 4, 6, 8, 10,12, 24 and $48 \mathrm{~h}$ of exposure. Changes in the previously mentioned variables were compared to a control group exposed to $20^{\circ} \mathrm{C}$ and salinity of 34 . The sedimentation evaluation was performed by observing the percentage of the area of the base of the glass bottle covered with sedimented microalgae, by visual observation. Changes in swimming and shape of the cells were evaluated for both suspended and sedimented cells, with the help of a conventional optical microscope. The microalgae density used for the tests was the same as that used for the larval feeding of $C$. caementarius $\left(80,000\right.$ cells $\left.\mathrm{mL}^{-1}\right)$. The microalgae used in this experiment were obtained from the university's central marine culture laboratory from intermediate cultures (8-L bottles) in the exponential phase, maintained in salinity of 34 and $20^{\circ} \mathrm{C}$, with a cellular density of $15 \times 10^{5}$ cells $\mathrm{mL}^{-1}$ for Nanochloropsis sp., and $6 \times 10^{5}$ cells $\mathrm{mL}^{-1}$ for Isochrysis galbana.

The salinities proposed for each of the experiments carried out in this study were defined based on the larval requirements of $C$. caementarius, described by Meruane et al. (2006a); Morales et al. (2006) and Morales \& Meruane (2012). The quality of the seawater and drinking water used to prepare the brackish mixtures at different concentrations was the same as that used inside the university's juvenile production laboratory (filtration at $1 \mu \mathrm{m}$ absolute and sterilization using QR80 UV equipment).

\section{RESULTS}

\section{Effect of salinity on the production of Artemia sp. nauplii}

The embryonic development dynamics observed in the incubation process of Artemia sp. cysts at different salinities were very similar in the three concentrations used $(13,15$ and 20) with a predominance of umbellar states at $12 \mathrm{~h}$ and nauplii after $16 \mathrm{~h}$ of incubation (Fig. $1)$.

For the three salinities, the analysis of the proportion of developmental stages (cysts, umbellar states and nauplii) at various incubation times showed significant differences between 12 and $16 \mathrm{~h}$ and between 16 and $20 \mathrm{~h}$ of incubation (chi-square $\left(\chi^{2}\right)$ table of contingency, $P<0.001)$. On the other hand, no significant differences were found between salinities when comparing the proportion of cysts, umbellar states and nauplii found for each of the incubation times $\left(12,16,20\right.$ and $24 \mathrm{~h}$ ) (chi-square $\left(\chi^{2}\right)$ table of contingency $P>0.05$ ) (Table 1).

Regarding the percentage of hatched cysts, no significant differences were found between salinities when holding incubation time consistent, but significant differences were found for salinities at different incubation times $(P \leq 0.001$, one-way ANOVA) (Table $2)$. The Holm-Sidak multiple comparisons test showed significant differences between 12 and $16 \mathrm{~h}(P \leq 0.001)$ and between 16 and $20 \mathrm{~h}(P \leq 0.001)$, but not between 20 and $24 \mathrm{~h}(P>0.05)$.

\section{Effect of refrigeration of decapsulated cysts on the production of Artemia sp. nauplii}

The daily hatching percentage of refrigerated cysts was between 71 and $86 \%$ (Table 3). No significant differences were found in the hatching percentages between any of the 15 days of sampling $(P>0.05$, oneway ANOVA).

\section{Effect of salinity on the behavior of microalgae used as live feed}

In the case of Isochrysis galbana it was observed that the reduction in the saline concentration of the medium could generate changes in the swimming capacity of the microalga, but not in its shape. On the other hand, for Nanochloropsis sp., reduction in salinity affected both the swimming capacity and the shape of the cell. For the T-Iso cells, a reduction in the cell swimming capacity was observed at $10 \mathrm{~min}$ of exposure at both 15 and 20 of salinities while for the control group (34) the reduction in swimming capacity started at $15 \mathrm{~min}$. This decrease in mobility caused continuous sedimentation of cells until $25 \mathrm{~min}$, with higher abundance at 15 , followed by 20 and 34 of salinities (Table 4). However, after 30 min of exposure, both the control group cells and those exposed to the two test salinities began to recover their mobility, achieving an almost total resuspension of the sedimented cells at $2 \mathrm{~h}$ of exposure for the control group and $4 \mathrm{~h}$ of exposure for salinities of 15 and 20. Likewise, the cells that remained in suspension showed no morphological changes or reduction in their swimming capacity.

In the case of Nanochloropsis sp., the reduction in cell swimming capacity began at $4 \mathrm{~h}$ of exposure for the three salinities (34, 20 and 15), and increased until 48 h. However, among the three salinities, the highest cell sedimentation occurred at 15,20 and the control group (Table 4). Microscopic observation of sedimented 


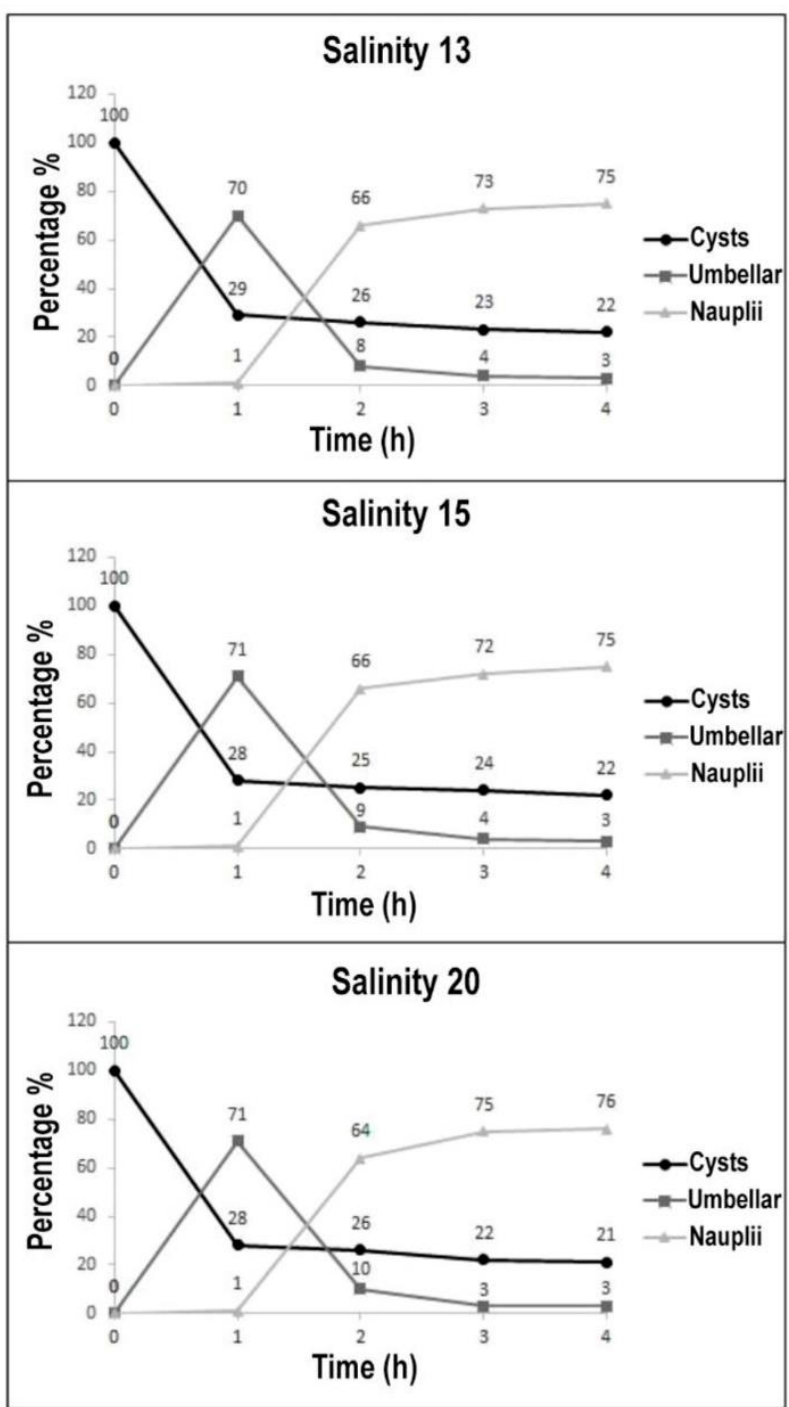

Figure 1. Incubation dynamics of Artemia sp. cysts for 24 $\mathrm{h}$ at different salinities.

Nanochloropsis sp. cells showed that after $10 \mathrm{~h}$ of exposure, cells exposed to 15 and 20 of salinity began to lose their spherical or ovoid shape, and began to form stationary conglomerates of cells (Fig. 2). This conglomerate formation process occurred more rapidly and in greater quantity for cells exposed at 15 of salinity, followed by cells exposed to salinity of 20 . Similar to that which occurred for T-Iso, the Nanochloropsis sp. cells that remained in suspension showed no morphological changes or reduction in their swimming capacity. On the other hand, for the mixture of the two microalgae, the effect of salinity was similar to that observed for each of them independently, at the three salinities (Table 4).

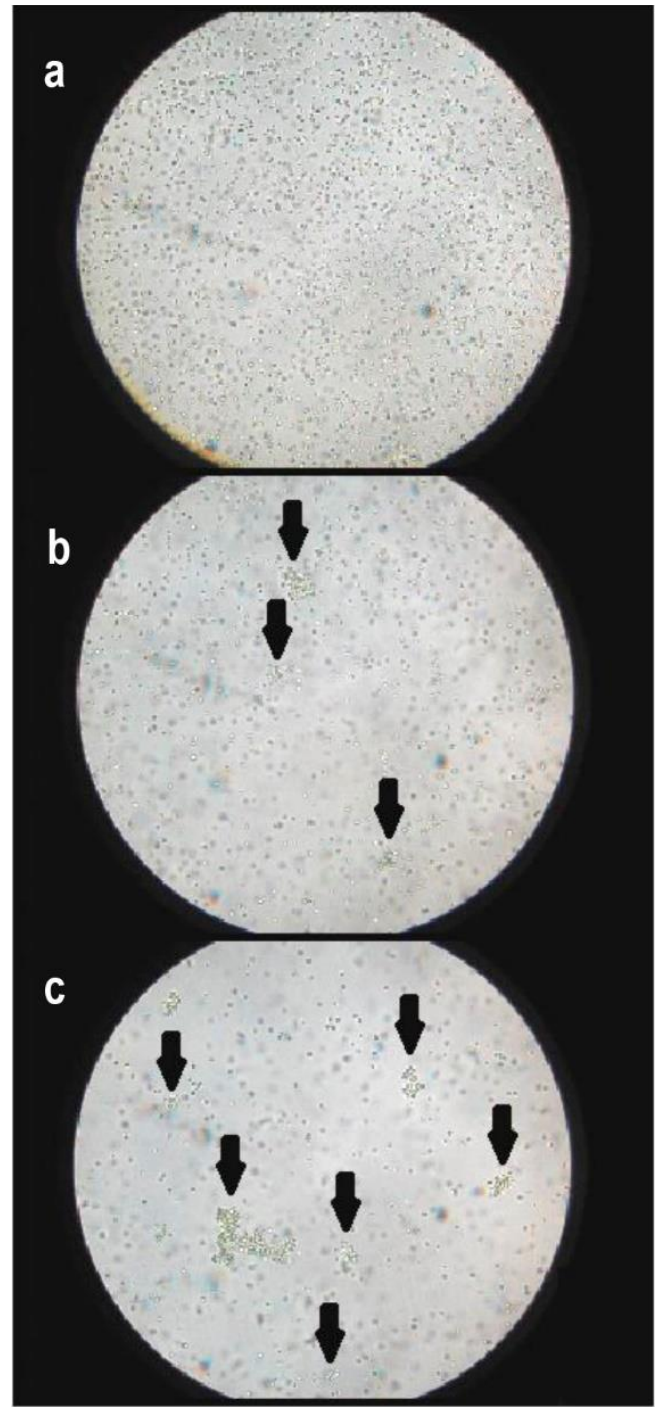

Figure 2. Formation of conglomerates sedimented cell of Nanochloropsis sp. after $24 \mathrm{~h}$ of testing (40x). a) Control group (no conglomerates), b) salinity of 20, c) salinity of 15. Increase of conglomerates at 15 salinity.

\section{DISCUSSION}

Successful larval culture and mass production of Cryphiops caementarius juveniles is time-consuming and requires management of environmental conditions to be successful. Adequate work protocols that distribute and organize the time for each of the operational activities within the culture centers is necessary. Several authors have reported drawbacks in juvenile production for this species, including the high number of zoea stages and the environmental and nutritional requirements associated with each stage (Munaylla, 1977; Rivera et al., 1983, 1987). However, recent 
Table 1. The average proportion of development stages (cysts, umbellar stages and nauplii) of Artemia sp., at different salinities and incubation times. Values with different letters between rows and columns show significant differences.

\begin{tabular}{cccc}
\hline \multirow{2}{*}{ Time (h) } & \multicolumn{3}{c}{ Salinity } \\
\cline { 2 - 4 } & 20 & 15 & 13 \\
\hline 12 & $(28-71-1)^{\mathrm{a}}$ & $(28-71-1)^{\mathrm{a}}$ & $(29-70-1)^{\mathrm{a}}$ \\
16 & $(26-10-64)^{\mathrm{b}}$ & $(25-9-66)^{\mathrm{b}}$ & $(26-8-66)^{\mathrm{b}}$ \\
20 & $(22-3-75)^{\mathrm{c}}$ & $(24-4-72)^{\mathrm{c}}$ & $(23-4-73)^{\mathrm{c}}$ \\
24 & $(21-3-76)^{\mathrm{c}}$ & $(22-3-75)^{\mathrm{c}}$ & $(22-3-75)^{\mathrm{c}}$ \\
\hline
\end{tabular}

research conducted by Meruane et al. (2006b) and Morales et al. (2006), obtained $C$. caementarius juveniles in batch-type production systems, with daily replacements of $100 \%$ of the water volume, constant temperatures and gradual modifications in salinity and feeding, according to the requirements of each development stage. These farming practices, together with the production of live feed, are the daily activities that demand the most time, resources and rigor, mainly during the first stages of development, when adequate feeding and environmental stability inside the culture

Table 2. The average percentage of hatching nauplii at different salinities and incubation times for each replicate (R). Values with different letters between rows and columns show significant differences.

\begin{tabular}{|c|c|c|c|c|c|c|c|c|c|}
\hline \multirow{3}{*}{ Time (h) } & \multicolumn{9}{|c|}{ Salinity } \\
\hline & \multicolumn{3}{|c|}{20} & \multicolumn{3}{|c|}{15} & \multicolumn{3}{|c|}{13} \\
\hline & R1 & $\mathrm{R} 2$ & R3 & R1 & $\mathrm{R} 2$ & R3 & R1 & R2 & R3 \\
\hline 12 & $1^{\mathrm{a}}$ & $0^{\mathrm{a}}$ & $0^{\mathrm{a}}$ & $1^{\mathrm{a}}$ & $0^{\mathrm{a}}$ & $0^{\mathrm{a}}$ & $0^{\mathrm{a}}$ & $0^{\mathrm{a}}$ & $1^{\mathrm{a}}$ \\
\hline 16 & $58^{b}$ & $58^{\mathrm{b}}$ & $64^{\mathrm{b}}$ & $58^{\mathrm{b}}$ & $57^{b}$ & $61^{\mathrm{b}}$ & $62^{b}$ & $62^{\mathrm{b}}$ & $65^{b}$ \\
\hline 20 & $74^{c}$ & $69^{c}$ & $73^{c}$ & $69^{c}$ & $68^{c}$ & $70^{c}$ & $73^{c}$ & $70^{\mathrm{c}}$ & $70^{c}$ \\
\hline 24 & $71^{\mathrm{c}}$ & $75^{c}$ & $74^{c}$ & $70^{c}$ & $69^{c}$ & $72^{c}$ & $73^{c}$ & $72^{c}$ & $71^{\mathrm{c}}$ \\
\hline
\end{tabular}

Table 3. Percentage of nauplii hatched for each sampling day of refrigerated cysts.

\begin{tabular}{ccrrrrrrrrrrrrrrr}
\hline \multirow{2}{*}{ Sample } & \multicolumn{11}{c}{ Days of refrigeration } \\
\cline { 2 - 16 } & 0 & 1 & 2 & 3 & 4 & 5 & 6 & 7 & 8 & 9 & 10 & 11 & 12 & 13 & 14 & 15 \\
\hline 1 & 73 & 79 & 78 & 80 & 74 & 82 & 80 & 78 & 72 & 72 & 73 & 83 & 77 & 79 & 77 & 78 \\
2 & 77 & 74 & 74 & 82 & 77 & 80 & 78 & 86 & 73 & 71 & 79 & 82 & 81 & 83 & 77 & 81 \\
3 & 78 & 76 & 81 & 80 & 72 & 79 & 86 & 79 & 79 & 79 & 77 & 77 & 81 & 73 & 78 & 80 \\
\hline
\end{tabular}

units increases larval survival (Meruane et al., 2006a; Morales et al., 2006).

The absence of significant differences in hatching percentages and in the incubation dynamics of Artemia sp. commercial cysts between salinities at incubation times, suggest that the dynamics of Artemia sp. embryonic development between 13 and 20 of salinity are independent of salinity, with a predominance of umbellar states at $12 \mathrm{~h}$ of incubation, and nauplii after $16 \mathrm{~h}$ of incubation. These results open the possibility of harvesting younger nauplii and therefore obtaining higher energy content (Vanhaecke et al., 1983) without significantly affecting the number of nauplii obtained. Also, this allows for the production of Artemia sp. nauplii under optimum temperature and salinity conditions for each larval development stage, and minimizes environmental variations within the culture units during feeding activities and also contributes to an increase in larval survival.
Although little is known about the nutritional requirements of each of its 18 different larval stages, some precedents report total mortality of the crop in the absence of food, in approximately five days (Viacava et al., 1978). On the other hand, increases in larval survival have been reported using diets composed of microalgae and Artemia sp. (Hartmann, 1958; Viacava et al., 1978; Rocha, 1985), reaching maximum values and metamorphosis by providing mixed diets that include Isochrysis sp., Monocrysis sp., Nannochloris sp. and Tetraselmis sp., together with nauplii of Artemia sp., filtered marine plankton and formulated feed (Munaylla, 1977; Sanzana \& Báez, 1983; Guadalupe, 1985; Rivera et al., 1987). The most current information available on successful experiences of larval culture of $C$. caementarius is presented by Meruane et al. (2006b); Morales et al. (2006) and Morales \& Meruane (2012), who report obtaining juveniles between 62 and 65 days of culture using a diet 
Table 4. Sedimentation of Nannochloropsis sp. and Isochrysis galbana cells exposed to different salinities. (-) No sedimentation, (+) scarce sedimentation, (++) low sedimentation, (+++) moderate sedimentation, (++++) high sedimentation. Scarce sedimentation is equivalent to $10 \%$ of the $10 \mathrm{~mL}$ sample vial bottom covered with microalgae, while low, moderate and high sedimentation is equivalent to 30,50 , and $100 \%$, respectively.

\begin{tabular}{|c|c|c|c|c|c|c|c|c|c|}
\hline \multirow{3}{*}{ Time } & \multirow{2}{*}{\multicolumn{3}{|c|}{$\frac{\text { Nanochloropsis sp. }}{\text { Salinity }}$}} & \multirow{2}{*}{\multicolumn{3}{|c|}{$\begin{array}{c}\text { Isochrysis galbana } \\
\text { Salinity }\end{array}$}} & \multirow{2}{*}{\multicolumn{3}{|c|}{$\frac{\text { Nano + T-Iso }}{\text { Salinity }}$}} \\
\hline & & & & & & & & & \\
\hline & control & 20 & 15 & control & 20 & 15 & control & 20 & 15 \\
\hline $5 \min$ & - & - & - & - & - & - & - & - & - \\
\hline $10 \mathrm{~min}$ & - & - & - & - & + & + & - & + & + \\
\hline $15 \mathrm{~min}$ & - & - & - & + & ++ & ++ & + & ++ & ++ \\
\hline $20 \mathrm{~min}$ & - & - & - & + & ++ & ++ & + & ++ & ++ \\
\hline $25 \min$ & - & - & - & + & +++ & ++++ & + & +++ & ++++ \\
\hline $30 \mathrm{~min}$ & - & - & - & ++ & +++ & ++++ & ++ & +++ & ++++ \\
\hline $2 \mathrm{~h}$ & - & - & - & + & ++ & +++ & + & ++ & +++ \\
\hline $4 \mathrm{~h}$ & + & + & + & + & ++ & ++ & + & ++ & ++ \\
\hline $6 \mathrm{~h}$ & + & + & + & + & + & + & + & + & + \\
\hline $8 \mathrm{~h}$ & + & + & + & + & + & + & + & + & + \\
\hline $10 \mathrm{~h}$ & ++ & ++ & ++ & + & + & + & + & + & + \\
\hline $12 \mathrm{~h}$ & ++ & ++ & ++ & + & + & + & + & + & + \\
\hline $24 \mathrm{~h}$ & ++ & ++ & +++ & + & + & + & ++ & ++ & +++ \\
\hline $48 \mathrm{~h}$ & +++ & ++++ & ++++ & + & + & + & ++ & ++ & +++ \\
\hline
\end{tabular}

composed of cells of Isochrysis sp., Nannochloris sp., Artemia sp. nauplii and formulated foods containing milk, egg and squid meat.

There are significant operational advances to be had in the production of Artemia sp. nauplii by maintaining specific salinity and temperature conditions as well as refrigerating decapsulated cysts for periods of up to 15 days. This method minimizes environmental changes within the culture units, which are associated with increases in C. caementarius larval mortality, and it extends the periodicity of hydration and decapsulation events of cysts, from daily to every two weeks, reducing by approximately $4 \mathrm{~h}(80 \%)$ the duration of daily activities for the production of live feed. Likewise, the Isochrysis galbana delivery in a single ration, and of Nanochloropsis sp. in two or more daily rations, together with the possibility of harvesting Artemia sp. nauplii, with fewer hours of life, improves feeding activities and nutrition by increasing microalgae availability and residence time in the water column and reduces the energy content loss of nauplii due to growth (Vanhaecke et al., 1983; Lavens \& Sorgeloos, 1996; Tacon, 2003). The results presented here provide preliminary information about production practices and management of the main organisms used as live feed in successful experiences of larval culture of $C$. caementarius, creating operational protocols that optimize time, supplies and human resources. Additionally, the information generated in this study optimizes the time dedicated to the activities and processes associated with shrimp larviculture, time that can be used to improve larval feeding strategies for $C$. caementarius as well as for other species of amphidromous crustaceans. Given the variety of farming and feeding techniques used in the larviculture of northern river shrimp, similar research should be carried out inside each culture center to optimize and individualize operational activities at different production scales.

\section{ACKNOWLEDGMENTS}

We want to acknowledge financing received by FONDEF D08I1104 for this research as well as from FONDEF project IT13I10012.

\section{REFERENCES}

Báez, P., Sanzana, J. \& J. Weinborn. 1983-84. Contribución al conocimiento de la morfología larvaria de Cryphiops caementarius, camarón de río del norte. Boletín del Museo Nacional de Historia Natural, Chile, 40: 153-172.

Bahamonde, N. \& Vila, I. 1971. Sinopsis sobre la biología del camarón del río del norte. Biología Pesquera, 5: 360.

Bauer, R.T. \& Delahoussaye, J. 2008. Life history migrations of the amphidromous river shrimp Macrobrachium ohione from a continental large river system. Journal of Crustacean Biology, 28(4): 622-632.

Elías, J. 1960. Contribución al comportamiento del camarón de río Cryphiops caementarius (Molina) Decapoda: Palaemonidae. Pesca y Caza, 10: 84-106. 
Guadalupe, R. 1985. Ensayos en cultivo masivo de larvas de camarón de río Cryphiops caementarius. Tesis de Ingeniería Pesquera, Universidad Nacional Agraria La Molina, Lima, $72 \mathrm{pp}$.

Hartmann, G. 1958. Apuntes sobre la biología del camarón de río Cryphiops caementarius (Molina) Palaemonidae, Decapoda. Pesca y Caza, 8: 17-28.

Hernández, J. 1981. Estudio bioecológico del camarón Cryphiops caementarius de los ríos Huasco y Copiapó. Convenio SERPLAC III Región, Atacama y Fundación Chile, 13699.

Jara, C.G., Rudolph, E.H. \& González, E.R. 2006. Estado de conocimiento de los malacostráceos dulceacuícolas de Chile. Gayana, 70(1): 40-49.

Lavens, P. \& Sorgeloos, P. 1996. Manual on the production and use of live food for aquaculture. Food and Agriculture Organization of the United Nations (FAO), Fisheries Technical Paper, 361: 295 pp.

Meruane, J.A., Morales, M.C., Galleguillos, C.A., Rivera, M.A. \& Hosokawa, H. 2006a. Experiencias y resultados de investigaciones sobre el camarón de río del norte Cryphiops caementarius (Molina, 1782) (Decapoda: Palaemonidae): historia natural y cultivo. Gayana, 70(2): 280-292.

Meruane, J., Rivera, M., Morales, C., Galleguillos, C. \& Hosokawa, H. 2006b. Juvenile production of the freshwater prawn Cryphiops caementarius (Decapoda: Palaemonidae) under laboratory conditions in Coquimbo, Chile. Gayana, 70(2): 56-64.

Morales, M.C. 1997. Desarrollo larvario del camarón de río Cryphiops caementarius (Molina, 1782) (Crustacea: Decapoda) en laboratorio. Tesis de Ingeniería en Acuicultura, Universidad Católica del Norte, Coquimbo, $114 \mathrm{pp}$.

Morales, M.C. \& Meruane, J. 2012. Indicadores de condición larvaria aplicados al camarón de río del norte Cryphiops caementarius, en condiciones de cultivo controlado. Latin American Journal of Aquatic Research, 40(3): 730-742.

Morales, M.C., Rivera, M., Meruane, J., Galleguillos, C. \& Hosokawa, H. 2006. Morphological characterization of larval stages and first juvenile of the freshwater prawn Cryphiops caementarius (Molina, 1782) (Decapoda: Palaemonidae) under laboratory conditions. Aquaculture, 261: 908-931.
Munaylla, U. 1977. Desarrollo larvario del "camarón de río" Cryphiops caementarius (Molina, 1832): determinación y descripción de sus estadios larvarios. Revista Documenta, 26: 13-16.

Norambuena, R. 1977. Antecedentes biológicos de Cryphiops caementarius (Molina, 1782) en el estero "El Culebrón" (Crustacea; Decapoda; Palaemonidae). Biología Pesquera, 9: 7-19.

Rivera, M., Meruane, J. \& Gil, R. 1987. Effects of salinity and food on larval survival and metamorphosis on Cryphiops caementarius (Molina, 1782) (Crustacea: Palaemonidae). Reports of the USA Marine Biological Institute, 9: 207-214.

Rivera, M., Schmiede, P. \& Meruane, J. 1983. Desarrollo larvario del camarón de río del norte Cryphiops caementarius (Molina, 1782) (Crustacea: Palaemonidae), en condiciones de laboratorio. Simposio Internacional de Acuicultura CoquimboChile, Coquimbo, pp. 315- 334.

Rocha, G.L. 1985. Cultivo de larvas de camarón de río Cryphiops caementarius (Molina, 1782) en laboratorio con alimento vivo. Tesis de Ingeniería Pesquera, Universidad Nacional Agraria La Molina, Lima, 49 pp.

Sanzana, J. 1976. Estadios larvarios del "camarón de río" Cryphiops caementarius (Molina) (Decapoda, Palaemonidae). Departamento de Agricultura, Universidad del Norte, 4: 47-55.

Sanzana, J. \& Báez, P. 1983. Desarrollo larvario de Cryphiops caementarius (Molina, 1782) en condiciones de laboratorio (Crustacea: Decapoda: Palaemonidae). Memorias de la Asociación Latinoamericana de Acuiculura, 5(2): 347-353.

Tacon, A.J. 2003. Aquaculture production trends analysis. Review of the state of world aquaculture. Food and Agriculture Organization of the United Nations (FAO), Fisheries Circular, 886: 5-29.

Vanhaecke, P., Lavens, P. \& Sorgeloos, P. 1983. International study on Artemia. XVIII. Energy consumption in cysts and early larval stages of various geographical strains of Artemia. Annales de la Société Royale Zoologique de Belgique, 113: 155-164.

Viacava, M., Aitken, R. \& Llanos, J. 1978. Estudio del camarón de río en el Perú 1975-1976. Boletín del Instituto del Mar del Perú, 3(5): 161-232. 